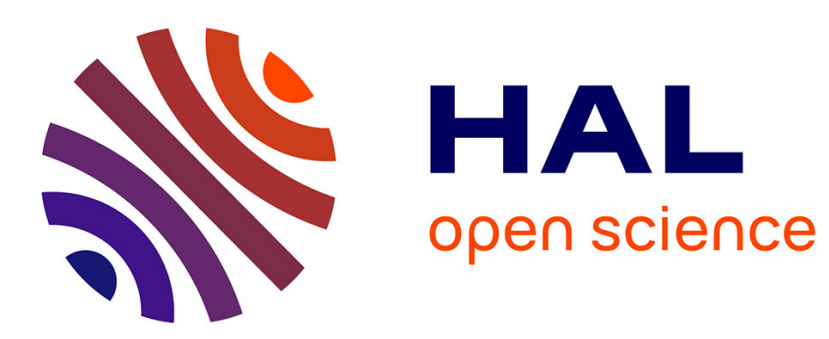

\title{
Electrospun Ni nanofibres as Pt supports for PEMFC electrodes
}

G Ercolano, S Cavaliere, D Jones, J Rozière

\section{To cite this version:}

G Ercolano, S Cavaliere, D Jones, J Rozière. Electrospun Ni nanofibres as Pt supports for PEMFC electrodes. ECS Transactions, 2015, 69 (17), pp.1237-1242. 10.1149/06917.1237ecst . hal-01252818

\section{HAL Id: hal-01252818 \\ https://hal.science/hal-01252818}

Submitted on 8 Jan 2016

HAL is a multi-disciplinary open access archive for the deposit and dissemination of scientific research documents, whether they are published or not. The documents may come from teaching and research institutions in France or abroad, or from public or private research centers.
L'archive ouverte pluridisciplinaire HAL, est destinée au dépôt et à la diffusion de documents scientifiques de niveau recherche, publiés ou non, émanant des établissements d'enseignement et de recherche français ou étrangers, des laboratoires publics ou privés. 


\title{
Electrospun Ni nanofibres as Pt supports for PEMFC electrodes
}

\author{
G. Ercolano, S. Cavaliere, D. Jones, J. Rozière \\ Institut Charles Gerhardt de Montpellier, UMR 5253 UM CNRS, Laboratoire des \\ Agrégats Interfaces et Matériaux pour l'Energie, Université de Montpellier, 34095 \\ Montpellier Cedex 5, France
}

\begin{abstract}
Nickel nanofibres were prepared by electrospinning followed by specific thermal treatments. $\mathrm{Pt} / \mathrm{Ni}$ fibrous electrocatalysts were obtained by galvanic displacement of the metal surface atoms with platinum. A novel, very fast $\mathrm{Ni}$ displacement assisted by microwaves is described. The $\mathrm{Pt} / \mathrm{Ni}$ nanofibres were characterised for their activity towards oxygen reduction for their application in PEMFC electrodes.
\end{abstract}

\section{Introduction}

Reduction of the fabrication and material costs and improved durability are pivotal issues to a successful market introduction of Proton Exchange Membrane Fuel Cells (PEMFC) (1). A more effective utilisation of the Pt catalyst and the use of more durable supports are the core of the development of novel, market ready PEMFC $(2,3)$.

Electrospinning is a scalable technique for the elaboration of nanowires of metals and metal oxides (4). The capability to finely control the diameter and composition of the nanowires makes this technique of interest in the search for novel catalyst support materials and morphologies $(5,6)$. We are interested in the possible paradigm shift from Pt nanoparticles supported on carbon to atomic layers of platinum (7) deposited on metals that could be achieved by coupling electrospinning to electrochemical Pt deposition techniques such as galvanostatic displacement of $\mathrm{Ni}(8,9)$.

In this work, nickel nanofibres were prepared by electrospinning and their surface atoms exchanged by galvanic displacement with $\mathrm{Pt}$ to obtain $\mathrm{Pt} / \mathrm{Ni}$ fibrous electrocatalysts that are characterised for their electrocatalytic properties. A novel very simple and fast approach of microwave-assisted Ni displacement is described, allowing the reduction of process duration from hours to $\leq 1$ minute.

\section{Experimental}

\section{Preparation of Ni nanofibres}

Nickel nanofibres were produced by electrospinning followed by thermal treatments. A $10 \%$ wt solution of polyvinylpyrrolidone (PVP) and nickel acetate $\left(1: 1_{\mathrm{wt}}\right)$ in ethanol and dimethylformamide $\left(7: 3_{\mathrm{vol}}\right)$ was electrospun at $1 \mathrm{kV} \mathrm{cm}^{-1}$ on a Linari Biomedical rotating drum collector combined with a syringe pump (KP Scientific) and a high voltage power supply (Spellman HV). The PVP carrier polymer was removed from the fibres by calcination at $600{ }^{\circ} \mathrm{C}$ in air during which the nickel salt was converted to nickel oxide. The calcination was conducted adopting a multistep ramp with dwells at $150{ }^{\circ} \mathrm{C}$ and $250{ }^{\circ} \mathrm{C}$ to reduce mechanical stress and ensure that the resulting nickel oxide would keep the original fibrous morphology. The calcined nanofibres were later reduced at $300{ }^{\circ} \mathrm{C}$ in an $\mathrm{Ar} / \mathrm{H}_{2}$ atmosphere $\left(\mathrm{H}_{2}\right.$ content $\left.5 \%\right)$ for $12 \mathrm{hrs}$. 


\section{$\underline{\text { Pt deposition onto nickel nanofibres }}$}

Platinum was deposited on the nickel nanofibres using two different approaches: a Simple Galvanic Displacement (SIGD) method adapted from a previous work (9) and a novel Microwave Assisted Galvanic Displacement Acceleration (MAGDA).

The same exchange solution was adopted for both approaches: $20 \mathrm{mg}$ of chloroplatinic acid hexahydrate $\left(\mathrm{H}_{2} \mathrm{PtCl}_{6} 6 \mathrm{H}_{2} \mathrm{O}\right)$ were dissolved in $6 \mathrm{ml}$ of $\mathrm{H}_{2} \mathrm{O}$ and the $\mathrm{pH}$ was adjusted to 7 using sodium hydroxide. The Pt containing solution was then added to $40 \mathrm{ml}$ of $\mathrm{N}_{2}$ saturated $\mathrm{H}_{2} \mathrm{O}$ containing $20 \mathrm{mg}$ of nickel nanofibres. A complete exchange would lead to $30 \%$ platinum loading.

For SIGD, the solution was stirred at room temperature for $48 \mathrm{hrs,} \mathrm{while} \mathrm{in} \mathrm{MAGDA}$ the solution was stirred for $60 \mathrm{sec}$ in a microwave (MW) reactor (MiniFlow 200SS Sairem) at $200 \mathrm{~W}$. The temperature reached after the $60 \mathrm{sec} \mathrm{MW}$ process was $\sim 55^{\circ} \mathrm{C}$. At the end of both exchange processes the nanofibres were collected by filtration and carefully washed with ethanol and water.

\section{Characterisation of the $(\mathrm{Pt}) / \mathrm{Ni}$ nanofibres}

The morphology of the electrospun materials before and after Pt deposition was characterised by scanning electron microscopy (SEM) using a FEI Quanta FEG 200 equipped with energy-dispersive spectroscopy analysis (EDS) and transmission electron microscopy (TEM) using a JEOL 1200 EXII.

$\mathrm{X}$-ray diffraction (XRD) patterns of the $\mathrm{Ni}$ supports were recorded at room temperature in Bragg-Brentano configuration using a PANAlytical X'pert diffractometer, equipped with a hybrid monochromator, operating with $\mathrm{CuK}_{\alpha}$ radiation $(\lambda=1.541 \AA)$, and using a step size of $0.1^{\circ} 2 \theta$ in the $2 \theta$ domain from 20 to $80^{\circ}$.

Electrochemical characterisation was carried out in a conventional three-electrode cell consisting of a glassy carbon rotating disk electrode (RDE) (working electrode, geometric area of $0.196 \mathrm{~cm}^{2}$ ), a reversible hydrogen electrode (reference electrode, RHE) and a platinum wire (counter electrode). A Pine bipotentiostat model AFCBP1 was used. All the potential values are referred to the RHE. Inks were prepared dispersing $5 \mathrm{mg}$ of catalysed support in $300 \mu \mathrm{L}$ of isopropanol, $20 \mu \mathrm{L}$ of water, and $15 \mu \mathrm{L}$ of 5 wt \% Nafion. These inks were then deposited onto the RDE surface with a micropipette to give a final Pt loading of $\sim 100 \mu \mathrm{g} \cdot \mathrm{cm}^{-2}$. (The SIGD had loading $\sim 25 \mu \mathrm{g} \cdot \mathrm{cm}^{-2}$ due to the low $\mathrm{Pt}$ content; for MAGDA, complete exchange was hypothesized and $30 \mathrm{wt} \%$ loading was used in the calculation). Cyclic voltammetry was carried out at $100 \mathrm{mV} / \mathrm{s}$ in $\mathrm{N}_{2}$ saturated $0.1 \mathrm{M}$ aqueous $\mathrm{HClO}_{4}$ and the electrochemical surface area (ECSA) of platinum was calculated by integrating the peak of hydrogen desorption from the $\mathrm{Pt}$ sites. Oxygen reduction reactions (ORR) were conducted on a RDE in an oxygen saturated $0.1 \mathrm{M}$ $\mathrm{HClO}_{4}$ aqueous electrolyte at increasing rotating speeds (400, 900, 1600, 2500 RPM) chosen in order to achieve equally spaced saturation currents (Koutecky-Levich).

\section{Results and discussion}

\section{Preparation and characterisation of Ni nanofibres}

The SEM images in Figure 1 show the nanofibres at the different stages of the synthesis and demonstrate how the fibrous morphology is successfully maintained despite the large volume variation resulting from the polymer removal and later by the nickel 
oxide reduction to metallic nickel. Fig. 1 a in particular shows that using optimised electrospinning deposition conditions and solution composition leads to defect-free nanofibres. The diameter is reduced by half during the reduction step, passing from 300 to $150 \mathrm{~nm}$ (Figures $1 \mathrm{~b}$ and $\mathrm{c}$, respectively).

a

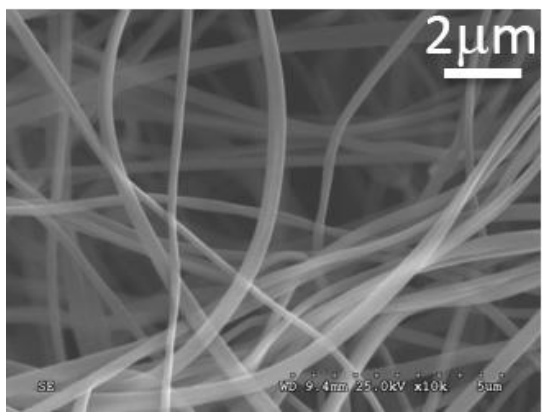

b

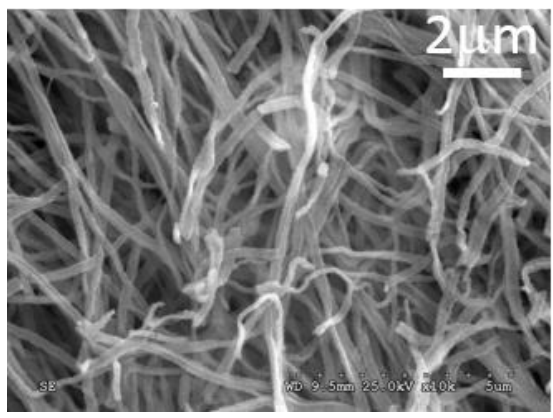

$\mathrm{c}$

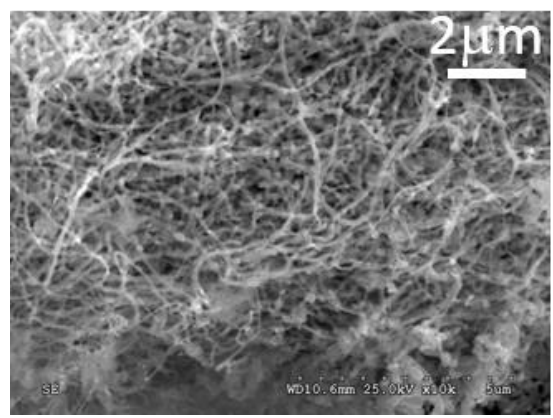

Figure 1. SEM images of a) PVP-nickel acetate, b) nickel oxide and c) nickel nanofibres

The XRD analysis on the calcined and reduced nanofibres (Figure $2 \mathrm{a}$ and $\mathrm{b}$ respectively) show that the former correspond to nickel oxide, while the latter are not yet completely metallic $\mathrm{Ni}$, since a residual $\sim 5 \%$ of the nickel is still in the oxide form. A longer reduction treatment or possibly a more aggressive reduction atmosphere will be implemented to completely reduce the nickel. It is important to notice that the XRD provides evidence for the presence of two separate phases ( $\mathrm{Ni}$ and $\mathrm{NiO}$ ), and not for an oxygen doped nickel or a nickel suboxide. It could be argued that the vast majority of the grains forming the fibres are pure metallic nickel and a small residual amount of grains are still nickel oxide.

\section{$\underline{\mathrm{Pt} \text { deposition and characterisation of } \mathrm{Pt} / \mathrm{Ni} \text { nanofibres }}$}

Nickel nanofibres were coated with Pt using a SImple Galvanic Displacement (SIGD) method and a Microwave Assisted Galvanic Displacement Acceleration (MAGDA).

The solution appearance after 48 hrs SIGD was rather unchanged, maintaining the initial yellow tint and intensity, while after the $60 \mathrm{sec}$ of MAGDA the solution had become completely transparent, suggesting that all the platinum had been removed from solution.

The TEM images in Figure 3 show platinum nanoparticles that are uniformly dispersed onto the metal wires, but no evidence for continuous film formation. The platinum loading for the SIGD samples estimated by EDS was $~ 5 \%$, vastly smaller than the $30 \%$ expected were exchange to be complete.

Cyclic voltammetry in $\mathrm{N}_{2}$ saturated $0.1 \mathrm{M} \mathrm{HClO}_{4}$ for the $\mathrm{Pt}$ SIGD/Ni (not presented) showed the presence of uncovered nickel (oxidation peak at $\sim 0.45 \mathrm{~V}$ ) as well as steadily increasing corrosion currents in the $1.0 \mathrm{~V}-1.2 \mathrm{~V}$ range. Both of these features are absent in the cyclic voltammetry of the sample obtained via MAGDA. 


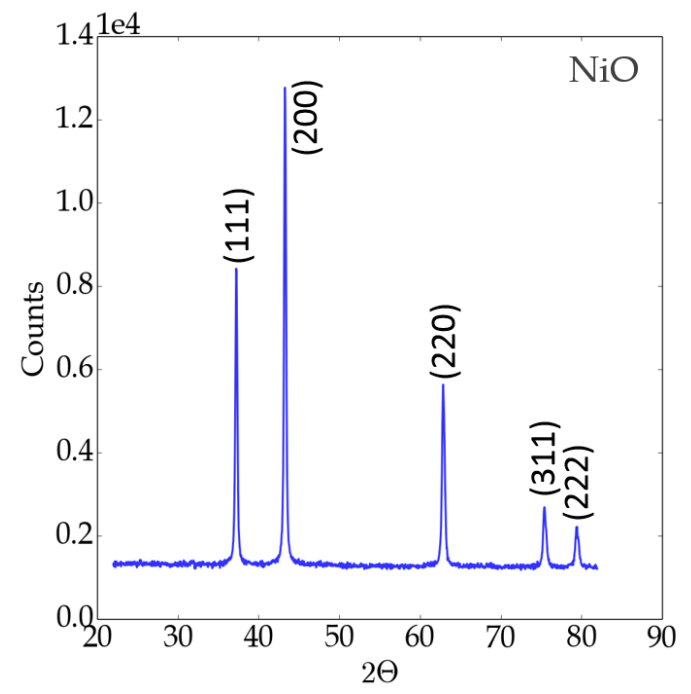

$\mathrm{b}$

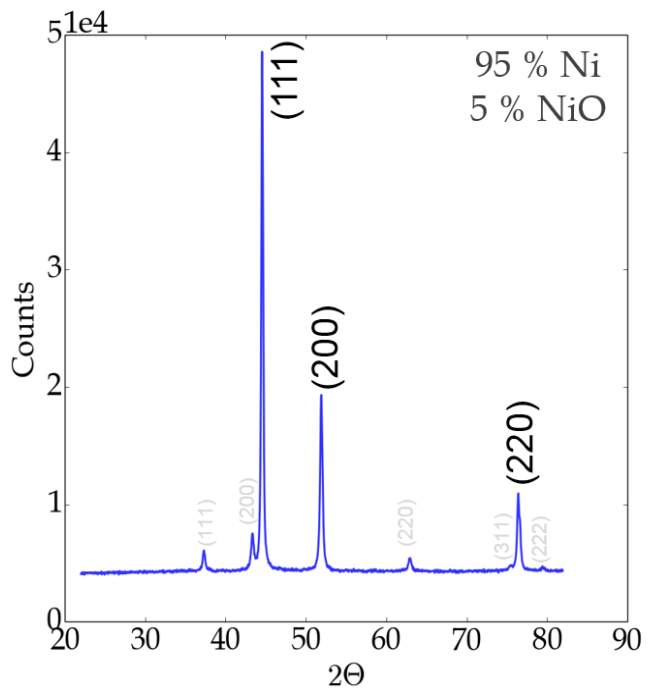

Figure 2. XRD analysis of a) nickel oxide and b) nickel nanofibres
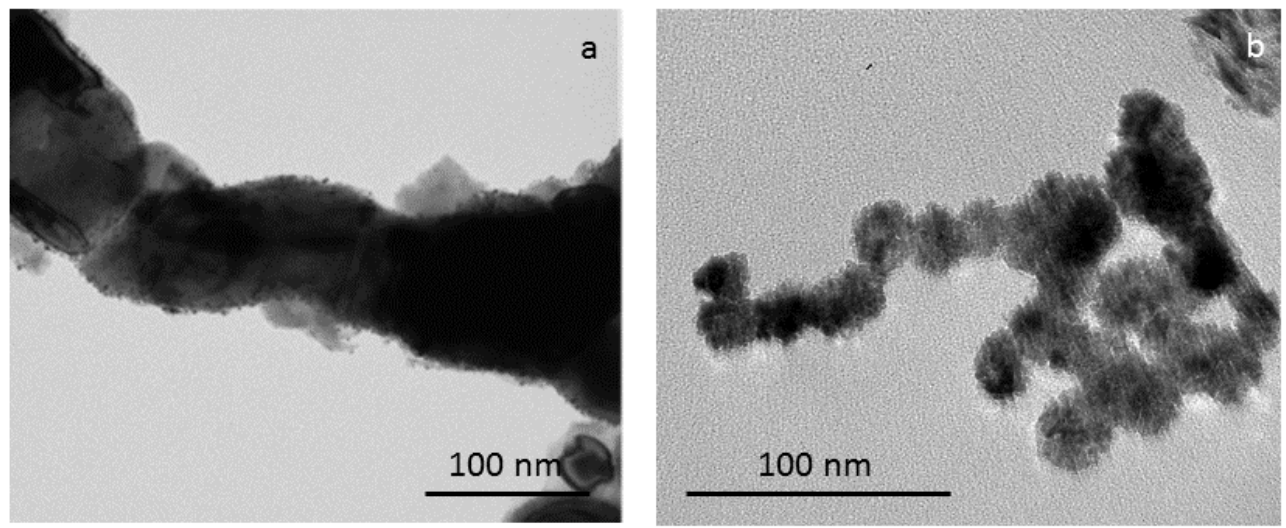

Figure 3. TEM micrographs of platinum on nickel nanofibres after the SIGD (a) and the MAGDA process (b).

ECSA calculated from the cyclic voltammetry were $42 \mathrm{~m}^{2} \mathrm{~g}^{-1}$ for the Pt SIGD/Ni and 21 $\mathrm{m}^{2} \mathrm{~g}^{-1}$ for the Pt MAGDA$/ \mathrm{Ni}$. The first is consistent with Pt nanoparticles of $\sim 5-7 \mathrm{~nm}$ in diameter, while the ECSA of the MAGDA Pt/Ni sample indicates the presence of large platinum particle agglomerates with a size of $\sim 18-20 \mathrm{~nm}$ as observed in the TEM micrographs in Figure 3. The fact that nickel does not seems to be exposed could be taken as an indication that a continuous/contiguous coverage of platinum is more likely.

The activity of the Pt/Ni nanofibres towards ORR was evaluated in acidic medium. From the oxygen reduction currents reported in Figure 4 it is evident that the SIGD sample evolves during the experiment, as the diffusion limited currents are not equally spaced, indicating that the sample capability to reduce oxygen is quickly decreasing.

The calculated mass activities at $0.9 \mathrm{~V}$ were $12 \mathrm{~A} / \mathrm{g}$ and $42 \mathrm{~A} / \mathrm{g}$ for the $\mathrm{Pt}$ sigD/Ni and $\mathrm{Pt}_{\text {MAGDA}} / \mathrm{Ni}$ respectively, and the mass activity of the latter is higher than $\mathrm{Pt} \mathrm{SIGD}_{\mathrm{SI}} / \mathrm{Ni}$ in all the evaluated range. 
$\mathrm{a}$

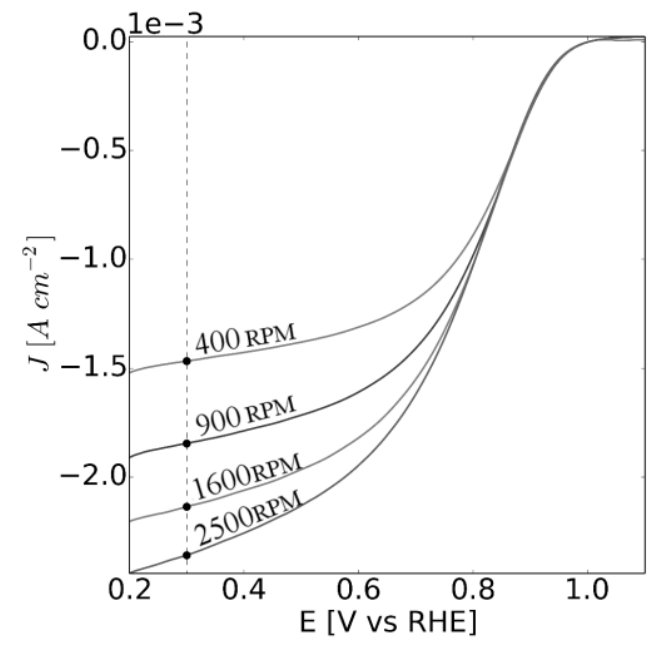

b

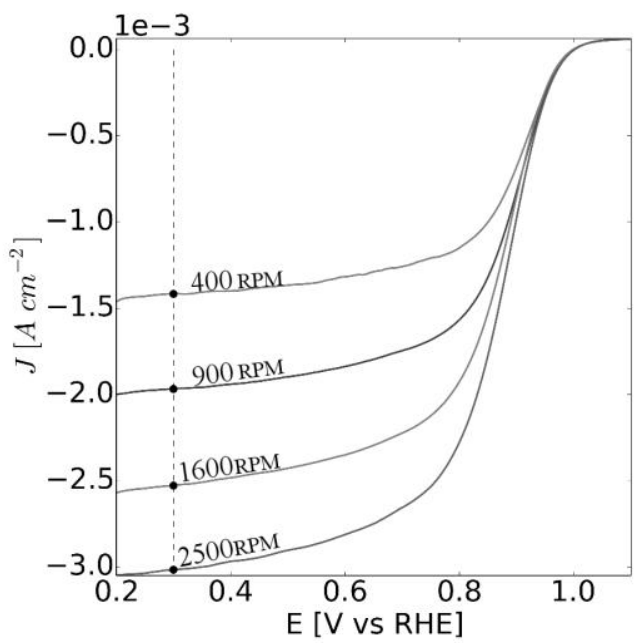

Figure 4. ORR at $5 \mathrm{mVs}^{-1}$ in $0.1 \mathrm{M} \mathrm{HClO}_{4}$ saturated with $\mathrm{O}_{2}$ at 400, 900, 1600, 2500 $\mathrm{RPM}$ a) Pt $\mathrm{SIGD}_{\mathrm{N}} \mathrm{Ni}$, b) Pt $\mathrm{MAGDA}_{\mathrm{N}} \mathrm{Ni}$

\section{Conclusion}

This work reports a simple and easily up-scalable method to produce Ni nanofibres covered with $\mathrm{Pt}$, by combining electrospinning and galvanic displacement. The simple $\mathrm{Pt}$ deposition method (SIGD) was improved and quickened by the application of microwaves (MAGDA). The electrocatalytic characterisation showed a better activity towards ORR of the sample prepared via the MAGDA approach. Further studies ex situ and in situ on the electrocatalyst durability are in progress to assess the applicability of $\mathrm{Pt} / \mathrm{Ni}$ fibrous metallic nanomaterials in PEMFC.

\section{Acknowledgments}

The research leading to these results has received funding from the European Research Council under the European Union's Seventh Framework Programme (FP/2007-2013)/ERC Grant Agreement no. 306682.

\section{References}

1. D. Jones and J. Rozière, in Encyclopedia of Electrochemical Power Sources, J. Garche et al., Editors, p. 667-679, Elsevier, Amsterdam (2009).

2. N. Yousfi-Steiner, P. Moçotéguy, D. Candusso, and D. Hissel, J. Power Sources, 194, 130-145 (2009).

3. Y. Shao, G. Yin, and Y. Gao, J. Power Sources, 171, 558-566 (2007).

4. S. Cavaliere, S. Subianto, I. Savych, D. J. Jones, and J. Rozière, Energy Environ. Sci., 4, 4761-4785 (2011). 
5. A. Bauer, L. Chevallier, R. Hui, S. Cavaliere, J. Zhang, D. Jones, and J. Rozière, Electrochim. Acta, 77, 1-7 (2012).

6. S. Cavaliere, S. Subianto, I. Savych, M. Tillard, D. J. Jones, and J. Rozière,, J. Phys. Chem. C, 117, 18298-18307 (2013).

7. R. K. Ahluwalia, X. Wang, A. Lajunen, A. J. Steinbach, S. M. Hendricks, M. J. Kurkovski, and M. K. Debe, J. Power Sources, 215, 77-88 (2012).

8. S. M. Alia, K. Jensen, C. Conreras, F. Garzon, B. Pivovar, and Y. Yan, ACS Catal., 3, 358-362 (2013)

9. S. M. Alia, B. A. Larsen, S. Pylypenko, D. A. Cullen, D. R. Diercks, K. C. Neyerlin, S. S. Kocha, and B. S. Pivovar, ACS Catal., 4, 1114-1119 (2014). 